\title{
THE DEVELOPMENT OF YEAR ONE STEM COMIC FOR SCIENCE AND MATHEMATICS SUBJECT
}

\author{
${ }^{1}$ Norazilawati Abdullah, ${ }^{2}$ Mazlini Adnan, ${ }^{3}$ Laili Farhana Ibharim, ${ }^{4}$ Tan Wee Hoe, \\ ${ }^{5}$ Dahlia Janan, ${ }^{6}$ Jafri Malin Abdullah, ${ }^{7}$ Noorzeliana Idris, ${ }^{8}$ Amila Saliza Abdul \\ Wahab \\ 1,2,3,4,5 Universiti Pendidikan Sultan Idris, \\ ${ }^{6}$ Universiti Sains Malaysia, \\ ${ }^{7,8}$ Kementerian Pendidian Malaysia
}

\begin{abstract}
This study aims to develop a year one STEM Comic for science and mathematics subjects. The STEM comic was developed based on the Technology Knowledge, Pedagogy and Content (TPACK) model. The development of this comic involves two phases which is development phase and assessment phase. However, this article only discusses the development phase of STEM comic. 13 Excellent teachers of science and mathematics from the Hulu Langat district were involved in the analysis of syllabus year one science and mathematics subjects and the preparation of scripts while the STEM comic illustrator was created by two lecturers from the Faculty of Art, Computing and Creative Industry from the Sultan Idris Education University. As a result, a STEM comic that contains 10 series for year one science and mathematics subjects has been successfully developed. This comic is expected to attract and enhance the achievement of year one students in science and mathematics. Implication of this study, STEM comic can be used by teachers as science and mathematics teaching aids.
\end{abstract}

Key words: Development, STEM Comic, Year One Students, Science and Mathematics

\section{INTRODUCTION}

The term STEM was first introduced in the United States in 1990-an originally STEM referred to by acronym SMET to represent Science, mathematics, engineering and technology (Sanders, 2009). In Malaysia, the STEM education chronology has actually started earlier than we expected. Even though STEM education is warmly talked about, in fact Malaysia has been working on science and technology since the 60's (Figure 1). JKPPT (1967) has recommended the projected ratio of students in upper secondary level was 2:3 (40:60) for the arts compared to the flow of Science and techniques from the year 1970. Integrated learning encompasses the disciplines of science, technology, engineering and math apply realworld context by linking educational institutions, communities and industry to produce talent and community based on STEM. Further, the development of STEM education in Malaysia is clearly significant in development plan for education Malaysia (PPPM) 2013-2015 (Ministry of education (MOE, 2013). The PPPM has been providing innovations in STEM education and is divided into three phases.

The first phase (2013-2015): Strengthen the quality of STEM education through the strengthening curriculum, testing and teacher training, and the use of various learning model (blended learning). The second phase (20162020): Interest and awareness in STEM through

Corresponding Author: Norazilawati Abdullah, Universiti Pendidikan Sultan Idris, email: nora@fpm.upsi.edu.my 
campaigns and cooperation and the third phase (2021-2025): An assessment of the success of the initiative in the first two stages and development plans the future with new initiatives and programs. The cooperation of the Ministry of science, technology and innovation with the Ministry of education and Ministry of higher education, an action plan, called the action plan a national STEM 2017-2025 has been developed to support the efforts in enabling activities STEM in particular in Malaysia. Thus, arguably STEM Education has become the main trend in the world of global education. Available countries developing rapidly, the number of pupils involved in STEM education is public and the national development policy is also focused on the development of STEM to produce talented people in the field of STEM. This effort is for the sake of the country's economic development in order to compete in the international platform.

\section{LITERATURE REVIEW}

Today has become a great discussion on how to integrate all four areas of Science, Technology, Engineering and Mathematics into education to implement STEM education. Many researchers in STEM education submitted a different point of view. According to a report presented by the Hanover Research in 2012, more and more supporters of STEM education support the interrelated nature of all subjects in the STEM and the need for implementing inter-disciplinary approach rather than assume the subject as a subject "silo" or a subject that stands on its own.

According to Sanders (2009), the integration of STEM education includes the approach that explores teaching and learning between any two or more of the STEM or between STEM subjects. In the Sanders report (2009) also stated that the implementation of integration in four areas of STEM education requires close collaboration amongst STEM teachers, STEM teachers' commitment and support from school administrators with a variety of problem-solving methods.

Integration of STEM is the approach to teaching the integration of subjects, and even the barriers between the four disciplines have been removed (Mazlini et al., 2016). Integrating Science, Technology, Engineering and Mathematics (STEM) helps students connect skills related to the use of skills in real-world applications by providing valuable learning contexts (Brophy, Klein, Portsmor \& Rogers, 2008). From the study, the researchers report and these experts can conclude that implementing STEM education teaching must involve the integration of subjects in STEM, either two or more subjects.

According to Morrison (2006), science, technology, engineering and math (STEM) education is often called meta-discipline, discipline creation based on integration of disciplined knowledge into a whole new 'knowledge'. This has bridged discipline among discrete disciplines now and is considered as an entity known as STEM. The subjects in STEM are closely related to each other and integration of these subjects can help students develop their knowledge, concepts and skills. Integration of Science, Technology, Engineering and Mathematics (STEM) helps students connect skills related to real-world applications by providing valuable learning contexts (Brophy, Klein, Portsmor \& Rogers, 2008).

In STEM's integration study, Lynn, Tamara, Carla and Gillian (2016) have identified five core features that distinguish STEM's education integration. The five features are: (1) the content and practice of one or more major disciplines in science and mathematics determine some of the key learning goals; (2) integration is engineering and engineering design of technology as context and / or international content components to be learned; (3) Engineering designs or engineering practices related to technology require the use of the concept of science and mathematics to justify designs created; (4) development of 21 st century skills is emphasized; (5) teaching context requires solving real-world problems or assignments through teamwork (Rodger, 2013).

Integration of STEM education does not mean creating a new subject in school. Integration of STEM education in the classroom is a kind of curriculum integration. The integration concept of the curriculum is complex and challenging, integration of subjects is more 
than a matter of just putting different subject areas together. The idea of curriculum integration comes from educators' awareness that real world problems are not divided into disciplines taught separately in schools (Czerniak et al., 1999). In most cases and case studies, educators across the academic and educational fields. According to Cleaver (2008), some teachers begin to see comics as an educational tool which can potentially generate interest students in academic subjects. Graphic novels have been used to teach various fields such as teaching social issues (Tabachnik, 2009), in the class of English for ESL students learn English (Boatright 2010), and also for the teaching of mathematical science in low ranking and the ranking of secondary schools (Chipman 2010).

According to Miller (2005), the use of comics is an effective medium in integrating various fields to achieve the desired objectives. This statement is also supported by Tilley (2008), when expressing the use of comics in education is a way to increase their student literacy. This is because graphic novels offer new values, variations, and approaches that have good visual effects in attracting young people to a particular

\section{METHODOLOGY}

The methodology of this study is divided into two phases. The first phase is the construction of STEM Comics while the second phase is the testing of the comic. However, the writing of this article focuses only on the development phase.

\section{STEM Comic Construction Phase}

The STEM Comic construction phase uses the TPACK model as shown in Figure 1 beginning with the preparation of knowledge and pedagogical content involving 13 outstanding Hulu Langat science and mathematics teachers. Four topics for science subjects and five topics for second-term mathematics are selected from the Curriculum and Assessment Standard Document (DSKP), Primary School Standard Curriculum curriculum require certain skills. For example, the content knowledge of the subject, pedagogical skills and technology and engineering skills.

Comics or graphic novels also known as increasingly attention among educators for use in

context, but they are also very useful for use across curricula, as well as offering alternatives to the use of traditional methods such as text and media another mass (Schwarz, 2002).

In addition to exposing readers to the diversity of areas in one script, the use of comics in education can also expose readers to new information and vocabulary. This can increase the students' interest in presenting knowledge in the storyline of a comic. The use of comics in learning also gives students the opportunity to explore and improve their thinking skills in a straightforward manner. This is the advantage that pupils will acquire when STEM comics science and mathematics are used in learning, and it will certainly bring a positive impact as stated by Gavigan and Kimmel (2013) that the use of graphic novels will bring positive changes in the lives of students.

(KSSR) as shown in Table 1. The constructive alignment of the content of knowledge and pedagogy between science and mathematics subjects is first implemented before the mapping of the comic storyline is done. In this comic, there are five main characters: Professor Megat Adam (Neuro-Gardener Sifoo), Megat Amir (Neuron Man), Princess Hanna (Neuron Woman), Megat Alif (Neuron Boy) and Princess Sarah (Neuron Girl). From technological aspects, the STEM Comic illustration is translated in the form of comics as a result of the storyline. Illustrators consisting of lecturers and UPSI students use Adobe Photoshop and Adobe Illustrator software. The STEM comic goes through the process of revising the appropriate language and graphics aspect according to the Ministry of Education (MOE) standards. 


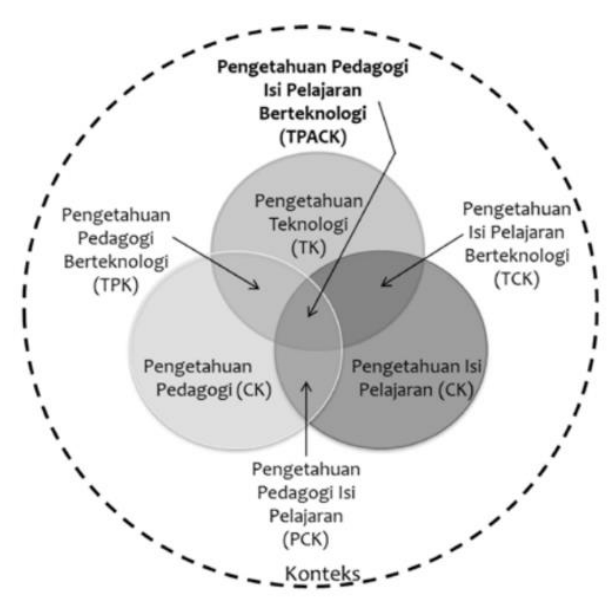

Figure 1 Model of Knowledge Technology, Pedagogy and Content (Muhammad Jailani \& Siti Raihana, 2016)

Table 1: Topic Science and Mathematics Subject

\begin{tabular}{|c|c|c|c|}
\hline Science & Series & Mathematic & Series \\
\hline Construction of base shape & $\begin{array}{l}\text { Series } 1,2 \\
\quad \text { and } 3\end{array}$ & Space & Series 1 \\
\hline Absorption & $\begin{array}{l}\text { Series } 4,5 \\
\quad \text { and } 6\end{array}$ & $\begin{array}{l}\text { Day and month, face of the } \\
\text { clock }\end{array}$ & Series 2 \\
\hline Land & Series 7 and 8 & Data management & Series 3 \\
\hline The face of the earth & Series 9 & $\begin{array}{l}\text { Size measure } \\
\text { Two-dimensional }\end{array}$ & $\begin{array}{c}\text { Series } 4,5,6,7 \\
\text { Series } 9\end{array}$ \\
\hline
\end{tabular}

\section{RESULT}

The STEM comic has been billed and contains 103 pages. Here is a summary of STEM Comics that has been produced. There are 10 series in this comic including a series of introductions. Each one has its own theme. The following themes are included for each series:

Series 1 - Playground

Series 2 - Happy Birthday Sarah

Series 3 - Month Committee of science and mathematics

Series 4 - The Rain Oh Rain

Series 5 - Sports

Series 6 - Rotten

Series 7 - Vegetable Project

Series 8 - Going back to hometown

Series 9 - Picnic in Port Dickson 
Figure 2 shows the display of several pages in STEM Comics

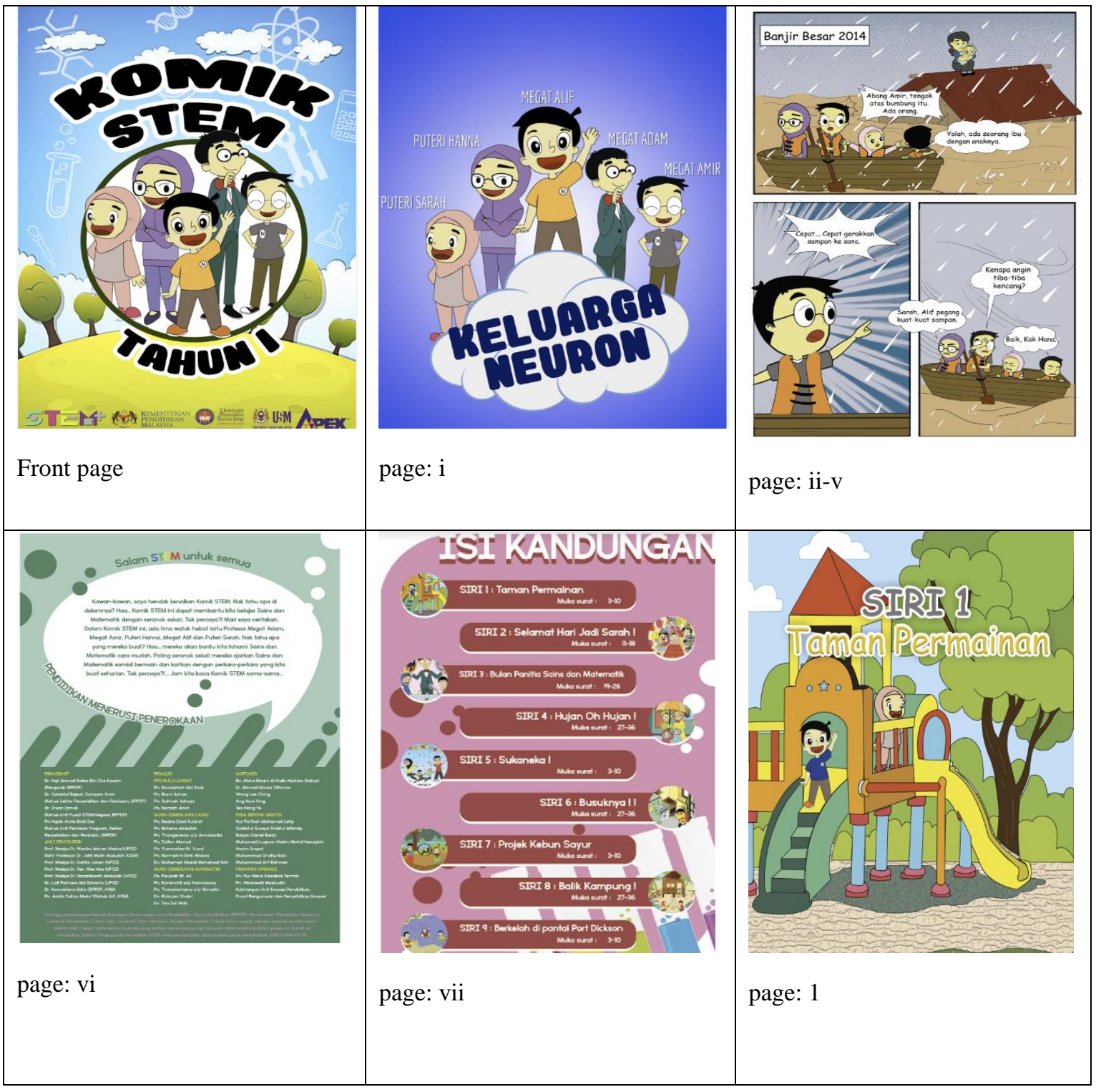


Norazilawati/ Journal of Engineering and Science Research, 3(6) 2019, Pages: 11-20

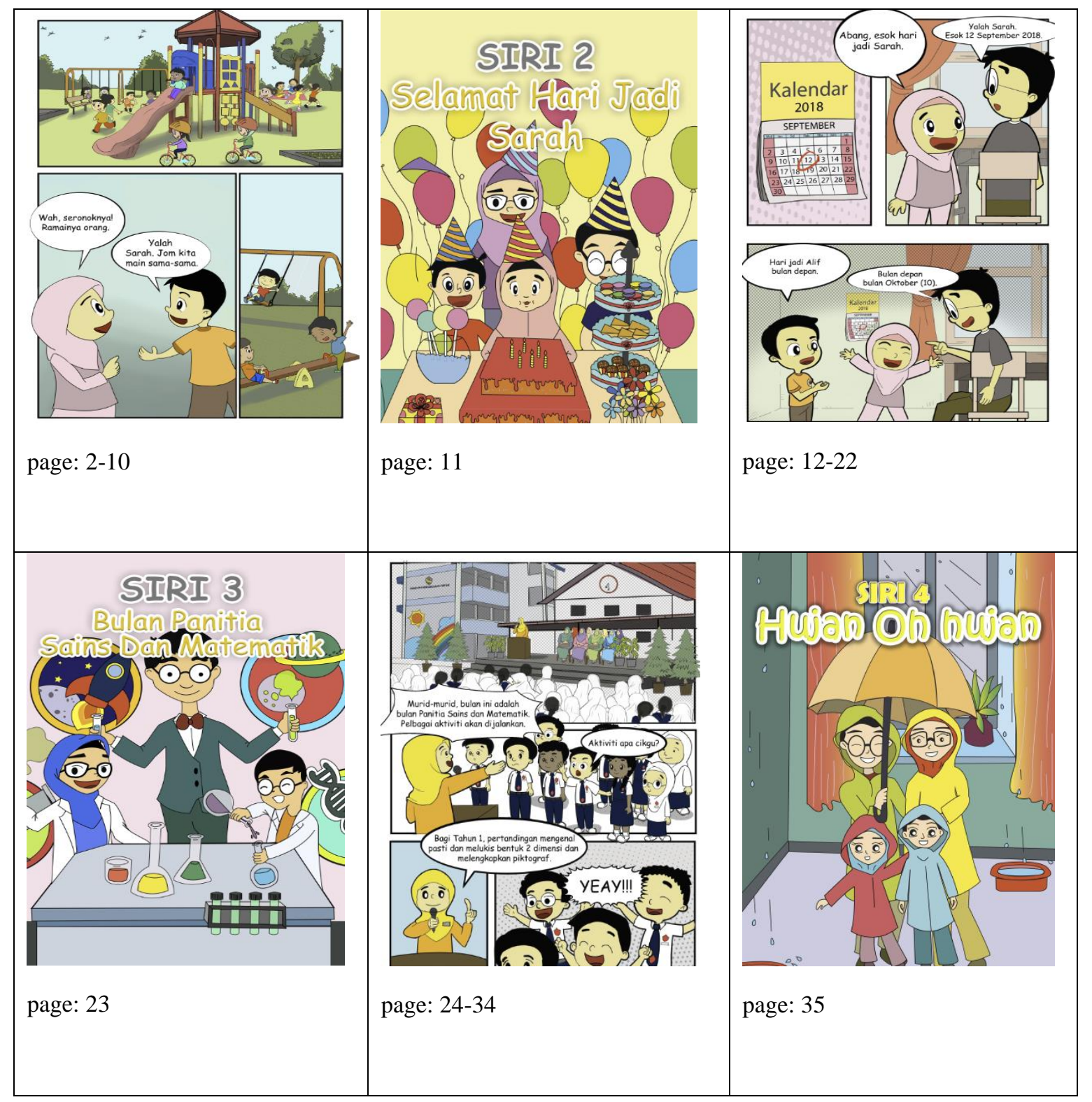


Norazilawati/ Journal of Engineering and Science Research, 3(6) 2019, Pages: 11-20

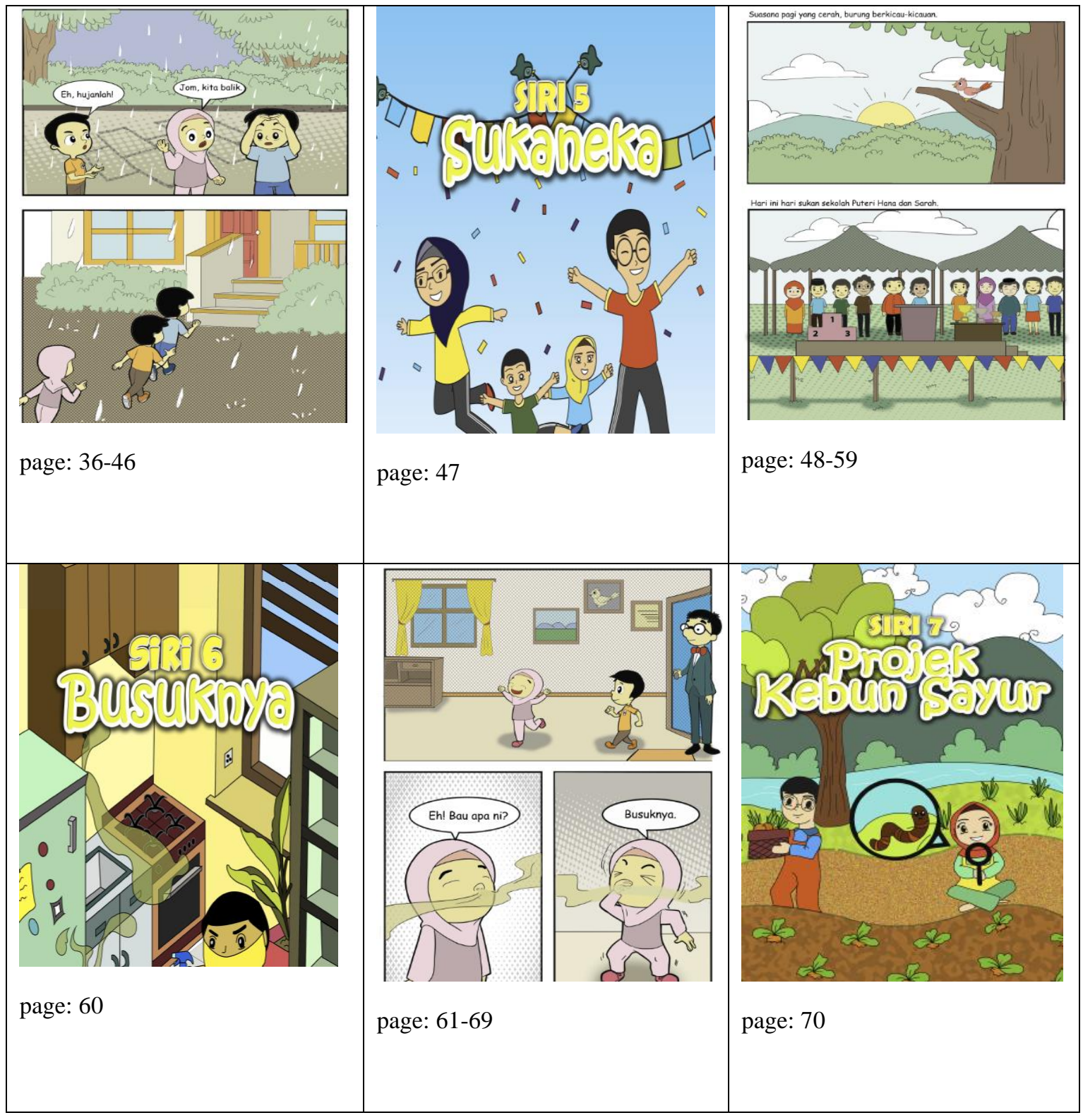




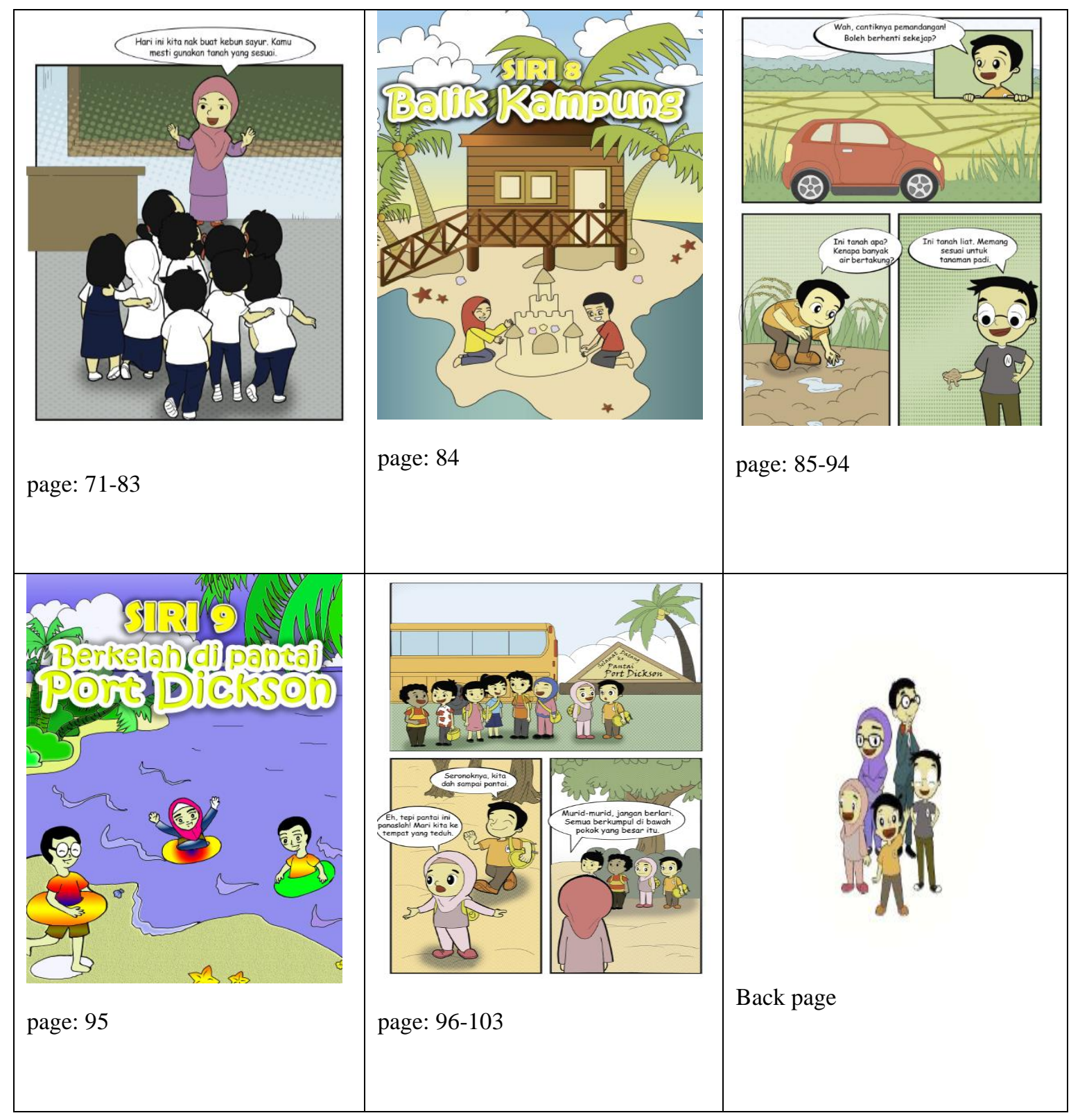

\section{CONCLUSION}

In order to ensure that Comic content is in good standing, four panel evaluators from various sectors such as the curriculum, examination and academic management division have been involved in providing comments, feedback and evaluation response to all developed comics series. The result of evaluation of assessors point out that comics developed meet the objectives and can be implemented very well. The findings of assessors also agree that all series of comics produced can be implemented and appropriate to the target group. This means that all the series and themes found in the resulting STEM comic are at a good and satisfactory level. It is hoped that this STEM Comic can be used as an additional reference material for year one students so that it 
Norazilawati/ Journal of Engineering and Science Research, 3(6) 2019, Pages: 11-20

can help increase students' interest and

\section{APPRECIATION}

This study is from the Research Outsourcing Education Policy Planning and Research Division (ROEPPRD), Ministry of Education Malaysia (MOE), cooperation between Universiti

\section{REFERENCE}

Brophy, S., Klein, S., Portsmore, M., Rogers, C. 2008. Advancing engineering education in P12 classrooms. Journal of Engineering Education, 97(3) 369-387.

Boatright, M. D. 2010. Graphic journeys: Graphic novels' representations of immigrant experiences. Journal of Adolescent \& Adult Literacy, 53: 468-76.

Cleaver, S. 2008. Comics and graphic novels. Instructor, 117 (6), $28-30$

Chipman, I. 2010. Graphic novels with science and math themes. Book Links 106(19-20): 810.

Czerniak, C.M., Weber, W.B., Sandmann, Jr. A., \& Ahern, J. 1999. Literature review of science and mathematics integration. School Science and Mathematics, 99(8), 421-430.

David, W. W. 2014. What Is STEM Education and Why Is It Important? Florida Association of Teacher Educators Journal, 1(14): 1-9. EDUCATION AT A GLANCE 2010: OECD INDICATORS ISBN 978-92-64-055988 C OECD 2010.

Judy, B. 2011. Five innovations from world war II. Retrieved from

http://bigdesignevents.com/2011/09/innovationsfrom-world-war-ii/

Gavigan, K., \& Kimmel, S. C. 2013. Graphic Novels, Comics, and the Common Core: Using Graphic Novels Across the Elementary Curriculum. achievement in science and mathematics.

Pendidikan Sultan Idris and Universiti Sains Malaysia (Research Code: 2018-0004-107-52). Thank you to all the people involved.

Jamaludin Ahmad. 2002. Kesahan, kebolehpercayaan dan keberkesanan komik program maju diri ke atas motivasi pencapaian di kalangan murid sekolah menengah negeri Selangor. Tesis PhD. Universiti Putra Malaysia.

Jeffries P. R. 2007. Simulation in Nursing Education: From Conceptualization to Evaluation. New York: National League of Nursing.

Lynn, A. B., Tamara, J. M., Carla, C. J. \& Gillian, H. R. 2016. Integrated STEM Education. STEM Road Map: A Framework for Integrated STEM Education. Taylor and Francis Inc. pp 23-37.

Mazlini Adnan, Aminah Ayob, Ong Eng Tek, Mohd Nasir Ibrahim, Noriah Ishak \& Jameyah Sheriff. 2016. Memperkasa pembangunan modal insan Malaysia di peringkat kanakkanak: Kajian kebolehlaksanaan dan kebolehintegrasian pendidikan STEM dalam kurikulum PERMATA Negara, GEOGRAFIA OnlineTM Malaysian Journal of Society and Space 12(1), 29 - 36.

Morrison, J. 2006. TIES STEM education monograph series, attributes of STEM education. Teaching Institute of Essential Science. Retrieved from https://www.partnersforpubliced.org/uploaded Files/TeachingandLearning/Career_and Tech nical_Education/Attributes\%20of\%20STEM\% 20Education $\% 20$ with $\% 20$ Cover $\% 202 \% 20$.pdf 
Norazilawati/ Journal of Engineering and Science Research, 3(6) 2019, Pages: 11-20

Miller, S. 2005. Developing and promoting graphic novel collections. Neal Schuman Pub.

Mohd Majid Konting. 2000. Kaedah Penyelidikan Pendidikan. Kuala Lumpur: Dewan Bahasa dan Pustaka.

Rodger W. B. 2013. The Case for STEM Education: Challenges and Opportunities. NSTA Press Book.

Sanders, M. 2009. STEM, STEM Education, STEMmania. December/January 2009. The Technology Teacher.

Schwarz, G. E. 2002. Graphic Novels for Multiple Literacies. Journal of Adolescent \& Adult Literacy, 46(3), 262-265. http://doi.org/10.2307/40017133

Song, J. 2008. Awakeing: Evolution of China's science and technology policies. Technology in Scinece, 30, 235-241.

Steck T.R., DiBiase W., Wang C. \& Boukhtiarov A. 2015. The use of open-ended problembased learning scenarios in an interdisciplinary biotechnology class: Evaluation of a problem-based learning course across three years. Journal of Microbiology \& Biology Education 13(1): 210. doi:10.1128/jmbe.v13i1.389.

Tabachnik, S. E., ed. 2009. Teaching the graphic novel. New York: Modern Language Association

Tilley, C.L. 2008. Reading comics. School Library Media Activities Monthly, 24 (9), 23 $-26$.

Yuan, G. 2013. Consultant Report Securing Australia's Future STEM: Country Comparisons, Report on China's STEM System. Australian Council of Learned Academies (ACOLA).

Zhong, X.-W., \& Yang, X.-D. 2007. Science and technology policy reform and its impact on China's national innovation system. Technology in Scinece, 29, 317325. 